\title{
ATYPICAL MULTICENTRIC "SCLEROSING HEMANGIOMA OF THE LUNG" A BENIGN MESENCHYMAL TUMOR OF THE PULMONARY INTERSTITIUM?
}

\author{
By T.H. Abdullas, M.D., Review Fcllow and Resident, Department of Pathology, \\ Universily of South Alabama Medical Center, Mobile, Alabama
}

W.J. Pollock, M.D., Assistant Professor of Pathology. University of South Alabama Medical Center, Mobile, Alabama

E.A. Dowling, M.D., Chief, Laboratory of Surgical Pathology and Professor of Pathology,

University of South Alabama Medical Center, Mobile, Alahama

\section{DOI: http://dx.doi.org/10.5915/16-1-12439}

\section{Abstract}

A caice of multicentric sclerosing hemangiomas of the lung with recurrent hemoptysis and previously unreported pneumothorax is presented. The variable histology of the tumor nodules presented the opportunity to make observatiuns pertinent to the histoggencsis of this tumor which bas been a subject of debate in surgical pathology for approximately 25 y'ears. Our observations suggest that sclerosing hemangiomas of the lung arises from pluri-potential mesenchymal cells in the pulmonary interstitioun. Focal differentiation of these interstitial cells, as noted in this case, into fibroconnective tissue, osteoid, fat, angiomatous tissue and bone may help cxplain the variable histology observed in casc reports. This variable differentiation supports a mescnchymal histogenesis. Ult rastructural sludies demonstrated that many of the interstitial colls had features of fibroblasts and nyofibroblasts.

1. Histogenesis
2. Multicentric
3. Sclernsing
4: Hemangioma
5. Fibroblasts/Myofibroblasts
6. Differentiation
7. Mesenchyme or Mesenchymal
Introduction

In 1956 Liebow and Hubbell coined the name "sclernsing hemangioma of the lung"l for a benign tumer of the lung that was composed largely of vascular tissue, fibrous connective tissue and stromal lipid. Since the original description of this levion, many cases have been reported in the literalure and there has been much discussion regarding the histogenesis of this tumor. This case ruport deals with a patient having several multiple tumor nodules in various stages of development, and afforded us the opportunity to study' the evolution of these lesions. Evidence noted in this case strongly suggests a mesenchymal histogenesis.

Address correspondence and reprint request to:

Dr. T. Abdulla

Dept. of Pathology and Laboratory Medicine

Alibar Clinic

4000 East 3rd Sireet

Panáma City, Florida 32401

\section{Case Report}

A 27 year old I ranian-American miale was adinitted to the University of South Alabamal Medical Center on $6 / 16 / 82$ and $7 / 23 / 82$ for evaluation of recurrent hemoptysis and spontaneous pneumothorax of the right lung. The patient gave a history of chest pain. dyspnea, and recurrent hemoptysis of three years duration. Eighteen months prior to his first admission he was evaluated at the Mobile County Health Department (Alabama) and was found to have a positive skin test for luberculosis. INH therapy was discontinued after one munth by him, because of gastrointestinal disturbances.

Significant physical lindings on thesc admissions were signs secondary to pneumothorax. Routine hemograrns and biochemical investigations were within normal limits. Sputum studies did not reved bacteria, fungi, or malignant cells, Chest x-rays showed nodules in the right middle and right lower lobes with an associated right pneumothorax (Scc. Fig. 1). A transbronchial biopsy on the first admission revealod only moderate interstitial fibrosis. During the second admission the patient had a thoracotomy wit) binpsies of the right middle and right lower lobes. Microscopic examination of the nodules demonstrated multiple sclerosing hemangiomas of the lung. Postthoracotony $x$-rays suggested that all nodules were removed with the biopsy resection.

Recovery was uneventful and the patient remained asymptomatic for nine months. In May of 1983 the patient again had an episnde of hemoptysis and chest pain but without recurrent pneumothorax. Rediograplic studies of the chest were negative and the patient was discharged to be lollowed in the outpatient clinics.

\section{Pathology}

Gross Findings: Biopsies of the right middle and right lower lobes were received in Carsoris formalin and measured $5 \times 2.5 \times 1 \mathrm{cms}$ and $4 \times 3 \times 1.5$ cms. respectively. The tissue was pinkish-brown and contained numerous subpleural and intraparenchymal nodular foci of grayish tissue. The surrounding parenchyma was congested and had decreased crepitance. A bony: spicule was encountered in the subpleura of the right middle lobe biopsy.

Histologic Findings: Sections of the biopsy specimen were prepared for light microscopy in the usual man- 


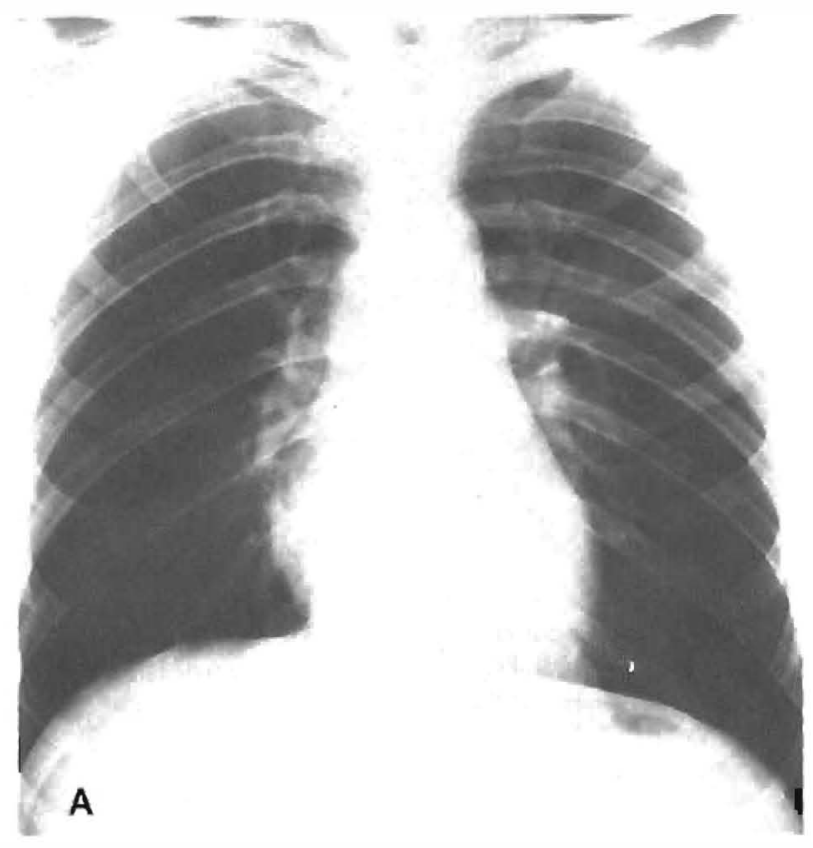

Figgure !.

A. X-ray af thest in 1979 showing no abnomalities.
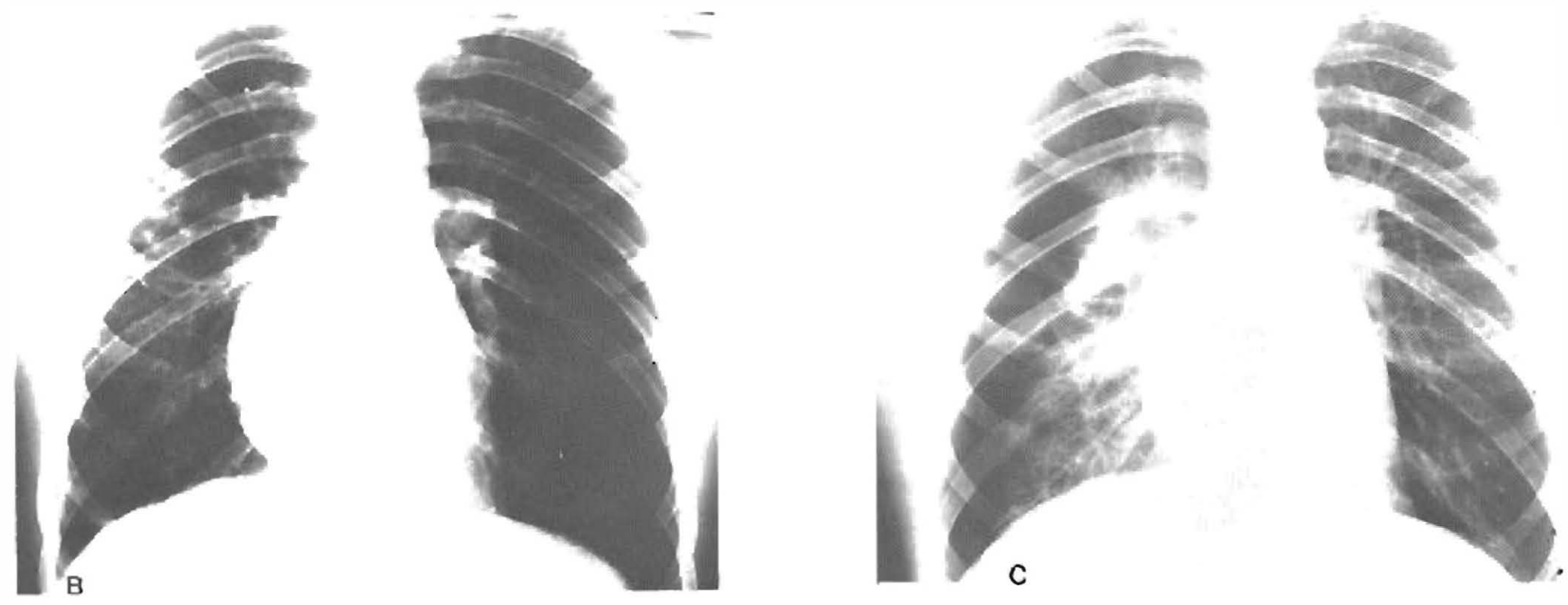

B. X-ray of ctrest in April 1982 shoving nodular densitles in rigest mid. لle and liswer lebex. 


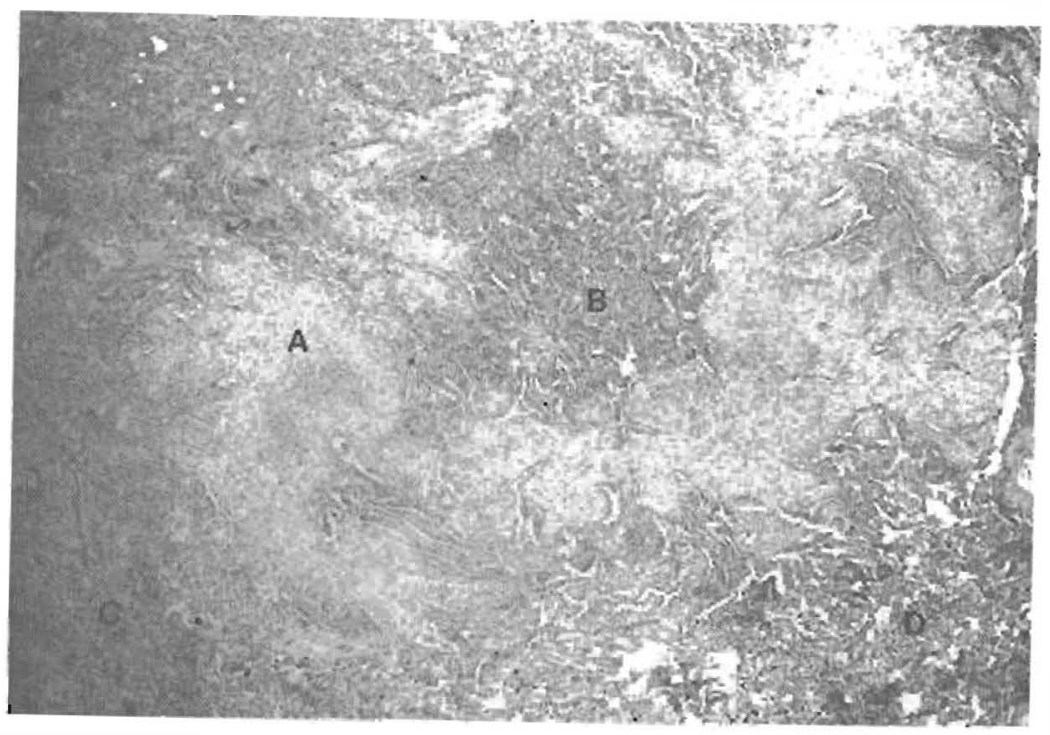

Figure $\mathrm{LI}$.

Four najor hisiological palterss of su-called "sclerosing Inernangiona" of the lung: A. Sclorotic: B. Papillary; C. Solid or Cellular; D. Hemorrhagic (Ilemotoxylin-Enxin. X43)

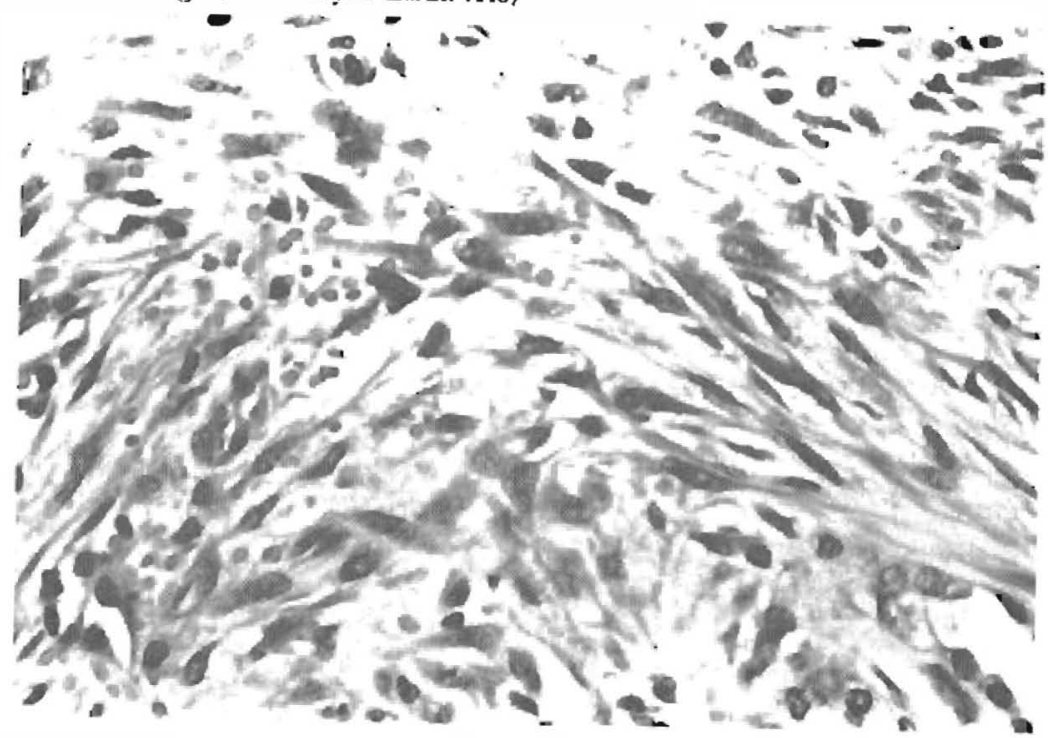

Figure III.

Red blond ocll extravasation was prominent in sone foct of sclerotic lissue. (Hemotoxylin-Easin. X666)

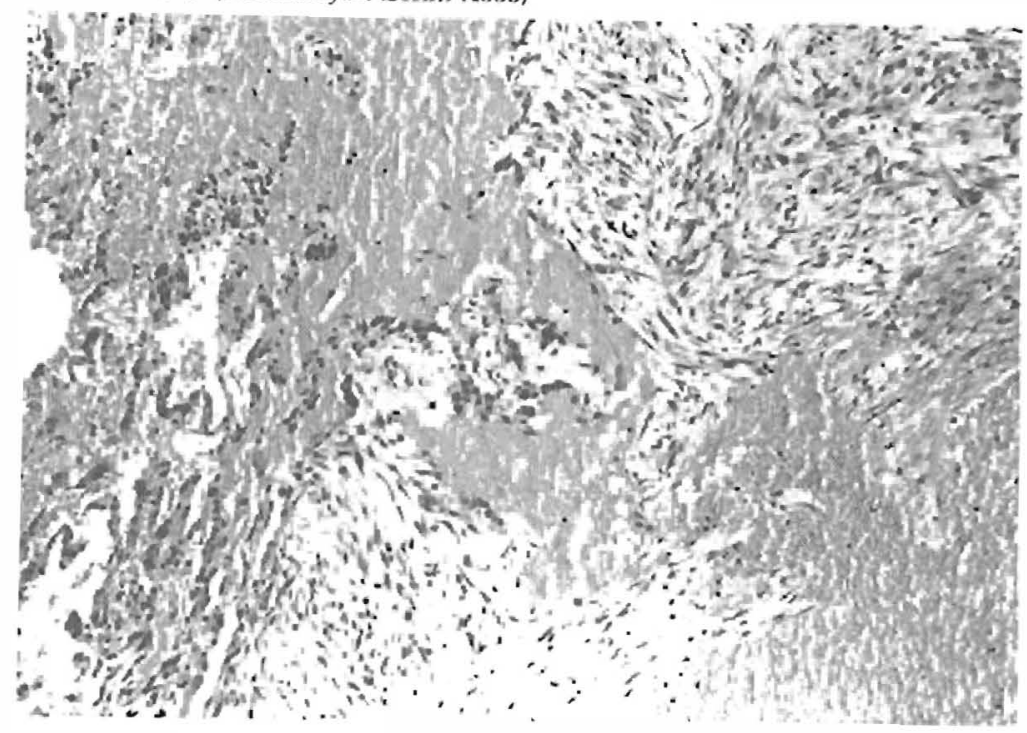

Fìgure IV.

A solerosing interstitial blood lake was sen disurting into the alveolar and pleural spece. This finding could explain mechanism of bemoptysis and spontanocus pneumothorax. (Hemetarvin-Easin. X170) 


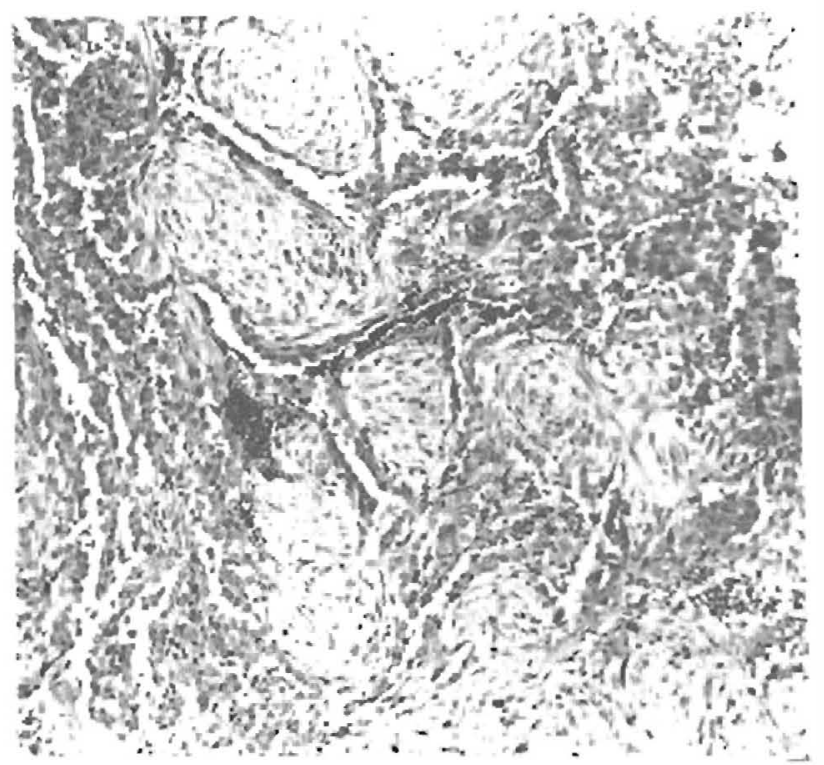

Figure $V$.

Young turnor nodules showed a whorling pattem of spincllo-shapod cells. (Hemotoxylin-Eosin. X170)
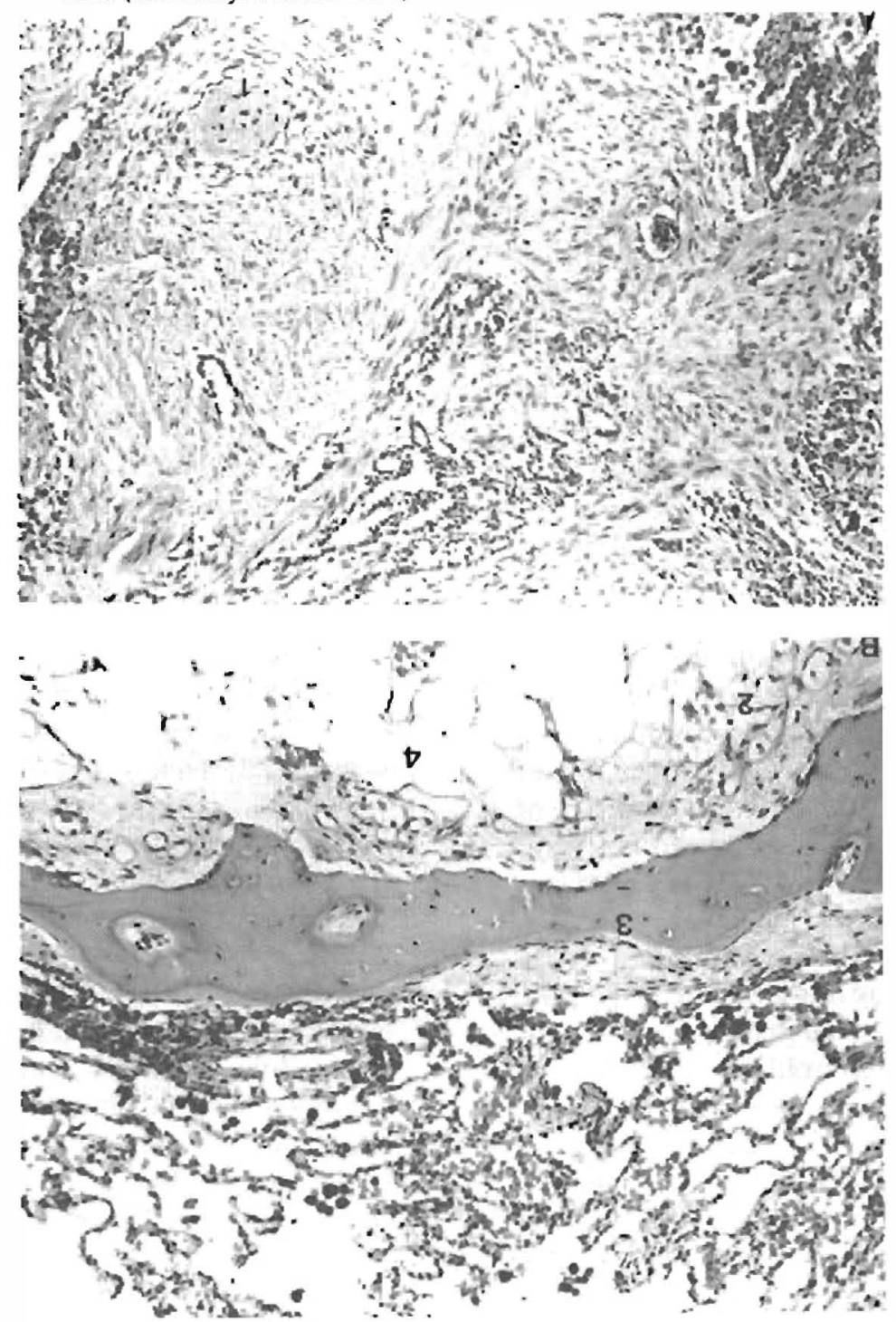

Figure VI

Turnor noxlules showing mescenchymal differestiation into A. Ostcoid (1) and B. Angjomatuus tisue (2) bone (3) and fal (4) werc observed.

(Hernatoxylin-Eosin. X170) 
ner and were stained with hemotoxylin, eosin, Masson's trichrome, reticulin, acid fast, Gonori's methenamine silver, Giemsa, iron, alcian blue/PAS and Verboeff-van Gieson stains. Light microscopic examination revealed variably sized noduler compressing the surrounding parenchyma in a pushing manner. The largest nodules in the right middle and right lower lobes measured 1 and $1.3 \mathrm{~cm}$, respectively, in diameter. These nodular kesions showed the clascical sclerotic, cellular (solid), hemorrhagic and papillary histologic pattems as described by Katzenstein, et al in $1980^{2}$ (See Fig. II). The sclerotic pattern which accounted for over $75 \%$ of the mass of these larger nodules was represented by proliferating fibroblastic cells with a whorled arrangement. Foci of red blood cel extravasation were noted in this sclerosis (See Fig. III). Varying amounts of ages of collagen were noted. Trapped alveoli and engorged blood vessels werp present within the fibrous connective tissue. The main tumor nodule in the right middle lobe biòpsy showed a large organizing interstitial lake of blood communicating with the alveolar and pleurad spaces (Sce Fig. IV). The larger nodules contuined pariillary foci in areas of alveolar entrapment and on the periphery of the nodules. The alveolar pneumocytes lining the papillary projections and entrapjed alveoli showed mild hyperplasia. The hemorrhagic compunents of these larger nodules were characterized by blood in entrapped and adjacent alveolar spaces. The solid or cellular pattern was represented by syncytia of collapsed and/or compressed clusters of alveoli. Other associated features involved scattered foci of hemosiderin-laden macrophages, lymphocytes, cholesterol clefts, adipose tissue and mast cells.

The smaller tumor nodules showed predominantly a proliferation of spindte-shaped cells arranged in a whorling pattern (See Fig. V). These smaller nodules ranged in size from 0.3 to $0.8 \mathrm{~cm}$ in diameter and had a sclerotic histolugic pattern composed of young collayen. Rarely, some of these nodules showed foci of differentiation into osteoid, angiomatous tissue, adipose tissue and bone (See Fig. VT). The pleura and subpleura of the right lower lobe biopsy showed organizing hemorrhage, fibrosis and small cystic spaces, probably lined by mesothelial cells. The histologic feature common to all nodules was the proliferation of spindle-shaped fibroblastic cells.

Electron Microscopy: The tissue submitted for electron microscopy was fixed in 10\% Carson's formalin, post-lixed in osmium teboxide, dehydrated in graded alcuhols, embedded in open and sectioned with an LKB ultratome. U\}tra thin sections were stained with uranyl acetate and lead citrate and examined in a Zeiss 109 electron misroscope. Ultrastructural examination of the pulmonary nodules revealed that the spindle cell component was composed largely of fibroblasts and myofibroblasts (See Fig. VII). the entrapped alveolar pneumocytes were separated from the spindle cell component by a well formed basenent membrane and numerous red cells could be identified within the alveolar spaces.

\section{Discussion}

The term "sclerosing hemangioma of the lung" was coined by Liebow and Hubbell in 1956". It clescribed a group of benign tumors characterized by sclerosing vasoformative tissue, old hemorrhage and siromal adipose tissue (lipid) ' $\approx$ a. The histological similarity to sclerosing hemangiomas in the skin undoubtedly influence th- - - 'pis name chosen for these lesions. Angiomatous tissuc was observed to be the major component and an endothelial cell origin was proposed. Clinically, sclerosing hemangiomas of the lung usually present as an asymptomatic solitary lesion on routine chest $x$-ray. Radiographically, these tumors are usually well circumscribed without involvement of the surrounding parenchyma. Some may show an air meniscus sign. ${ }^{4}$ Some authors have reported that most lesions are seen in the right lung fields, $2: 8$ while others have reported no predilection for either lung. ${ }^{7}$ Sclerosing hemangiomas of the lung are more common in the periphery and subpleura. Bronchial involvement has not been reported. Scant hemoptysis is the most common symptum and may be accompanied by conghing, chest pain, dyspnea and respiratory infertions. Our patient was unusual in that he had multiple lesions and several episodes of spontaneous pneumothorax. This tumor predominates in women. ${ }^{1}$ \& 5 . 7 a $n$ in In contrast, our case was of a male. We can find no previous report of spontaneaus preumuthorax assuciated with sclerosing hemangioma of the lung.

Katzenstein, et al in 1980 reviewed 51 cases of this tumor and described sclerutic, hemorrhagic, cellular and papillary patterns. ${ }^{2}$ Chan, et al in $1982^{7}$ observed these major histologic patterns in their series of 14 cases from Hong Kong. 'The variable histologic appearance of sclerosing hemangioma of the lung probably reflects a combination of mesenchymal histogenesis, differentiation and reaction. Proposed cells of origin include the endothelial cell, ${ }^{8} \&$ \& 11 12 13 14 15 10 un undifferentiated alveolar lining mesenchymal cell, ${ }^{17}$ pneumocytes, ${ }^{7}$ to 18 19 20 ol 22: fibroblaxts $^{23}$ and most recently, mesothelium. ${ }^{24}$ Even congenital origins have been proposed by some authors. ${ }^{25}$ this case of multicentric nodules provided a rare opportunity to study multiple lesions in various stages of development in a single patient. The smallest and presumably the youngest of the lesions in this patient were composed entirely of fibroblastic cells with young (myxoid) collagen. Utrastructural examination of these smaller lesions demonstrated spindle-shaped cells with fibroblastic differentiation. Some of the larger and presumably older lesions were observed to contain hyalinized collagen as well as combintions of other differentiated mesenchymal elements, including asteoid, bone, adipose tissue and vascular tissue. 


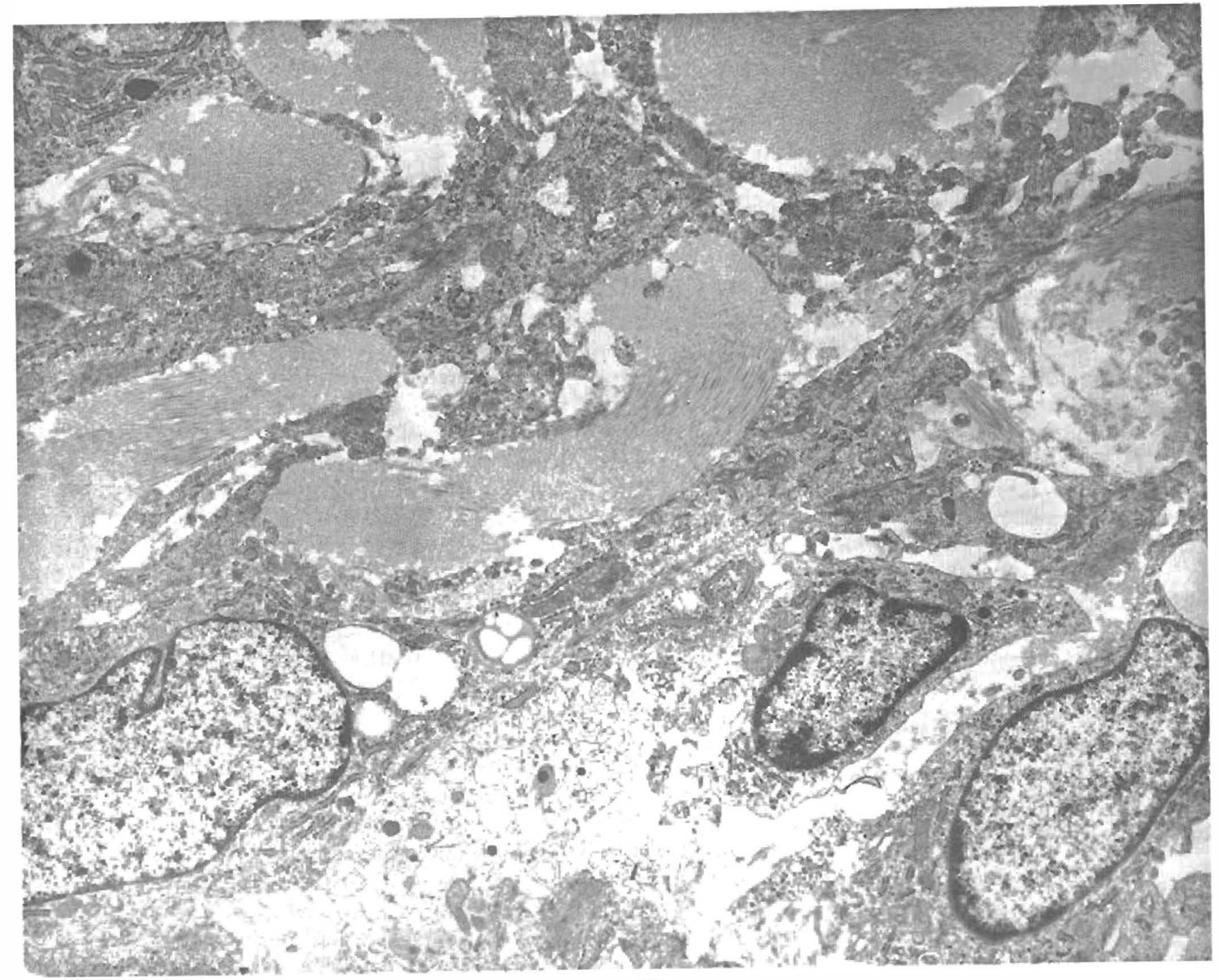

Figure VII.

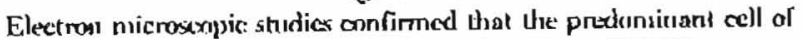
benign proliferation is the filumblast-myafilyroblast. ( $\mathrm{X} 3(\mathrm{M} M)$ 


\section{FIGURE VIII: Some Cells and Tissue Derived from Masenchyme}

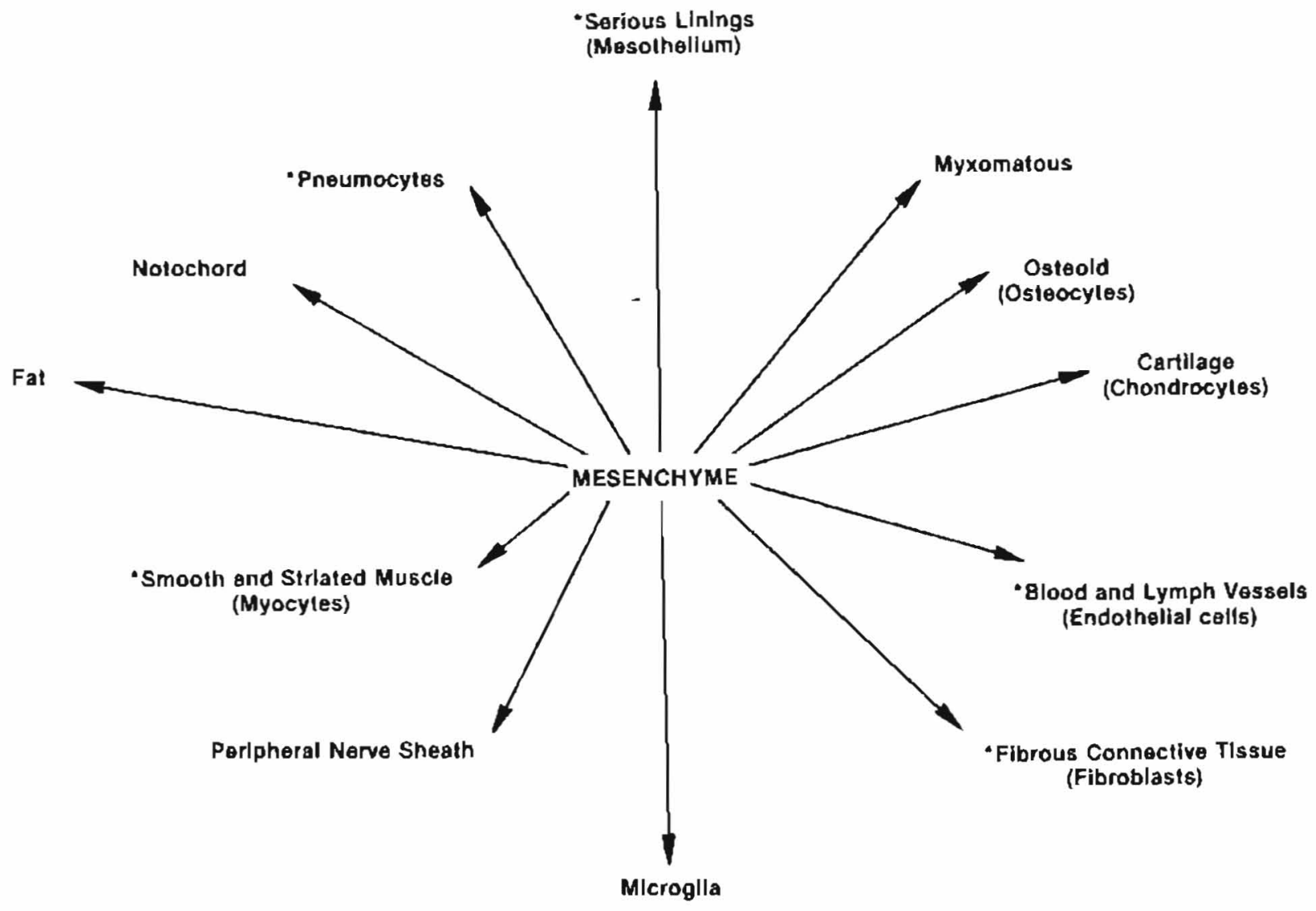

- Tlssue with a mesenchymal histogenesis normally found in the pulmonary intersiltium and associated parenchyma. Striated muscles are not lound. 
These observations suggest that sclerosing hemangiomas of the lung arise from undifferentiated pluipotential mesenchymal cells of the pulmonary interstitium. It is our belief that the epithelial components as represented by the Iype II pneunocytes dre. entrapped by the proliferating fibrous connective tissue. This ent rapping fibrous connective tissue is also responsible for the alveolar clustering prodincing the papillary component of some lesions. A mesenchymal concept of histogenesis readily explains the variable histologic patterns that have been described in slcernsing hemangiomas (See Fig. VIII).

It is paradoxical that whit were once classified as sclerosing hemangiomas of the skin are now fibrous histiocytomas. The varied mesenchymal differentiation potential noted in sclerusing hemagioma of the lung could be encompassed by calling it a benign mixed mesenchymal tumor of the pulmonary interstitiurn. Although the term sclerosing hemangioma is perhaps a misnomer, it may be desirable to retain this terminolgy. because of the unique clinical, historical and morphological characteristics of this lesion. A mesenchymal histogenesis can best explain the common and varied histology of this lesion. Inevitably, we feel that sclerosing hemangioma of the lung will be classified with fibrohistiocytic lesions as are "sclerosing hemangiomas" of the skin.

\section{Acknowlegemcnts}

We are grateful for the critical comments of Dr. William Cardncr, Chairman of the Department of Pathology, the technical assistance of Mr. Reede nelson Cinoley and the varied support of all at the University of South Alabama Medical Center whu contributed to the realization of this paper.

\section{References}

1. Liebow AA and Hubbell DS: Sclerosing hemangioma (histiocytoma, xanthoma) of the lung. Cancer 9:53, 1956.

2. Katzenstein AA, Gmelich et al: Sclerosing hemangioma of the lung, a slinicopathologic study of 51 cases. Am. J. Surg. Path. 4:343, 1980.

3. Kuzela DC: Uttastructural study of post inflammatory "rumor" of the lungs. Cancer 36:149, 1975.

4. Bank YW, Shinn KS and Choj BS: The air meniscus sign in slcerosing hemangiona of the lungs. Diag. Radiol. 127:27, 1978.

5. Arean WV and Wheat MW: Sclerosing hemangioma of the lung. A case report and review of literature. An. Rev. Resp. Dis. 85:261, 1962.

6. Webls WR and Gamsu G: Case Reports Sclerosing hemangioma of the lungs. Brit. J. Radiol. 50:213. 1977.

7. Chan K, Gibbs AR et al: Benign sclerosing pneumocytoma of the lung. (sclerosing hemangioma). Thorax, 37:404, 1982.

8. Miller DR: Benigh tumors of the lung and trachcobronchial tree. Ann. Thoracic Surg. $8: 542,1969$.

9. Mori S: Sclerosing hemangioma of the lung. Dis. of Chest $54: 71,19668$.

10. Palacios J. Esribana $P$ et al: Sclerosing hemangioma of the lung. An ultrastructural study. Cancer 44:949, 1979.

11. Kay S, Still WTS et al: Sclerosing hemangioma of the lung. Ar endothelial or epithelial neoplasm? Hum. Path. 8:468, 1977.

12. Joshi K. Shankar SK et al: Multiple sclerosing hemangiomas of the lung. Post Graduate Med. \}. 56:50, 1980.

13. Haas JE, Yunis EF at al: Ultrastructure of a sclerosing hemangioma of lung. Cancer 30:512, 1972.

14. Tomita T, Dixon A et al: Sclernsing vascular variant of a plasma cell lumor. Hum. Path. 11:197, 1980.

15. Chantarakul N. Sakjyalak $P$ and Khamcharoenpurn V: Sclerosing hemangioma of the lung. Report of a casc with ultrustructural study. J. Med. Assoc. thailand. 63:360, 1980.

16. Kaufman C, Goldberg $M$ and Tyazi NS: Nonneoplastic sclerotic pulmonary lesion (sclerosing hemangioma). Review of a case. Am. Rev. Resp. Dis. 104:742, 1970.

17. Spencer H: Pathology of the Lungs. Oxford, Third ed. Pergannor Press, Inc, 1977, pp. 933-3936.

18. Hitl Gs and Eggleston JC: EM study of so-called "pulmonary sclcrosing hemangioma: Report of a case suggesting epitelial origin. Cancer 30: 1092, 1972.

19. Kahn L and Dietrich B: Sclerosing hemangioma of the lung. A case report. S. African Med. J. 49:971, 1975.

20. Hellman $\mathrm{E}$ and Fiener $\mathrm{H}$ : the role of the clectron microscope in the diagnosis of unusual peripheral lung tumors. Hum. Path. 9:589. 1978.

21. Kennedy A: "Sclerosing hemangioma of the lung: An alternative in its development." J. Clinc. Path. 26:972, 1973.

22. Mikuz $G$, Szinca $G$ et al: Sclerosing angioma of the lung. Case report and electron microscopic investigation. Virchow Arch. Path. anat. Hist. 385:93, 1979.

23. Nair S, Nair K et al: Fibrous histiocytoma of the lung (sclerosing hemangioma variant?). Chest 65:465, 1974.

24. Katzenstein $A$, Louise $A$ et al: So-called sclerosing hemangioma of the lung - evidence for mesothelial origin. Anr. J. Surg. Pach. 7:3, 1983.

25. Rubin EH, Rubin $M$ et al: Circumscribed sclerosing hemangioma of the lung appearing as coin lesions. Cancer 18:634, 1958. 